\title{
The Inedita Homily In transfigurationem Domini (BHGn 1980a): A compilation using Proclus of Constantinople
}

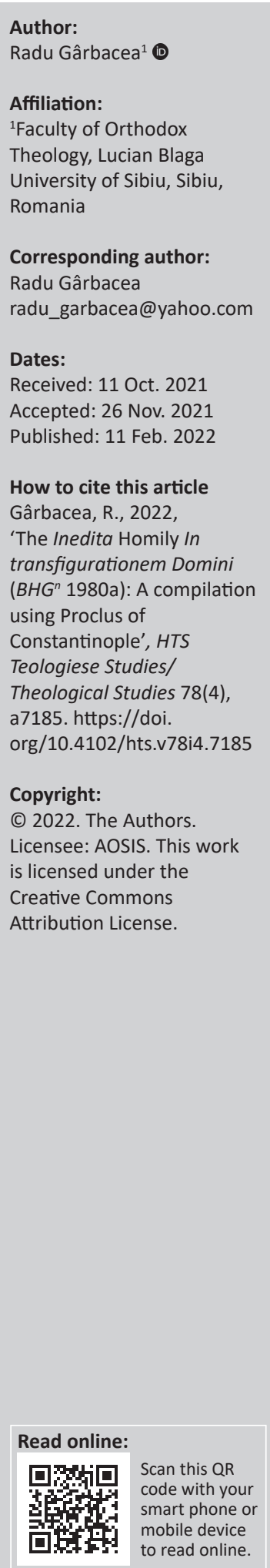

\begin{abstract}
In his inventory of the manuscript tradition of the homilies on the Transfiguration, Maurice Sachot stated that folios 46r-55r of the codex Parisinus graecus 1611 contain the homily In transfigurationem Domini (BHG 1980 a). He also stated that this text is unedited and that it is most probably a recension of the homily In transfigurationem Domini (CPG 5807; BHG 1980) attributed to Proclus of Constantinople. To date, however, this homily has remained unpublished and unstudied. After a brief presentation of the codex Parisinus graecus 1611, this article brings to light a surprise that emerges from examining folios 46r-55r of the Parisian manuscript.

Contribution: The article proves that the homily In transfigurationem Domini (BHG $\left.{ }^{n} 1980 \mathrm{a}\right)$ is not a recension of the homily on the Transfiguration (CPG 5807; BHG 1980), but a compilation for which the beginning of the homily on the Transfiguration attributed to Proclus of Constantinople was used.

Keywords: In transfigurationem Domini; Proclus of Constantinople; CPG 5807; BHG 1980; BHG 1980a; the Transfiguration.
\end{abstract}

\section{Introduction}

At the end of the 19th century, in his brief description of manuscript 1611 in the Greek collection of the Paris Library, ${ }^{1}$ Henri Omont drew attention to the fact that folios 46r-55r contain the homily on the Transfiguration by Patriarch Proclus of Constantinople ('Procli, CP. Patriarchae, homilia in Transfigurationem'), but without giving any information on the incipit or desinit (Omont 1888:106). In 1968, François Halkin also gave a brief description of the manuscript Parisinus gr. 1611, noting next to folios 46r-55r 'transfiguratio, oratio Procli $B H G^{n}$ 1980a' (Halkin 1968:226). Although he stated that folios 46r-55r contain the homily on the Transfiguration attributed to Proclus of Constantinople, already inventoried in the Bibliotheca Hagiographica Graeca (BHG) with the inventory number 1980, Halkin proposed another inventory number, namely 1980a. In the augmented version of the BHG published in 1969, namely Auctarium Bibliothecae Hagiographicae Graecae $\left(B H G^{a}\right)$, Halkin reproduced

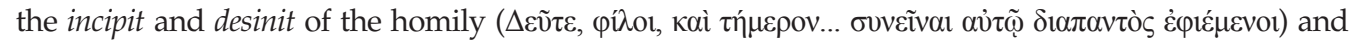
drew attention to the fact that this manuscript was omitted by the Jesuit François-Joseph Leroy (1967:100-105) in his inventory of the manuscript tradition of the homily In transfigurationem Domini (CPG 5807; BHG 1980) (ed. Halkin 1969:324). The editors of the third volume of the Clavis Patrum Graecorum (CPG) placed the number $B H G^{n}$ 1980a alongside the number BHG 1980 for the homily on the Transfiguration listed among the works of Proclus of Constantinople (CPG 5807) (Geerard 1979:136; Geerard \& Noret 2003:136). They equate the homily In transfigurationem Domini (CPG 5807; BHG 1980) with the homily on the Transfiguration transmitted by the Paris manuscript. ${ }^{2}$ In Novum Auctarium Bibliothecae Hagiographicae Graecae $\left(B H G^{n}\right)$, published in 1984, Halkin did not provide any further information about this text, merely reproducing what he had supplied in the earlier editions (ed. Halkin 1984:378). Three years later, in his inventory of the manuscript tradition of the homilies on the Transfiguration, Sachot stated that the homily $B H G^{n} 1980 \mathrm{a}$ is an unedited text belonging to Proclus, Patriarch of Constantinople, and that it is most probably a recension of BHG 1980 ('Il doit s'agir très vraisemblablement d'une recension de BHG 1980') (Sachot 1987:110). In 1993, Costas N. Constantinides and Robert Browning, although providing a detailed description of the Parisian codex in their work on dated Greek manuscripts from Cyprus, tell us only that folios 46r-55r contain the homily on the Transfiguration of 'Proklos, patriarch of Constantinople', and reproduce the incipit of the text (1993:328). 1.A digital copy of the manuscript is available online at Grec 1611/Gallica (https://gallica.bnf.fr/ark:/12148/btv1b107234374/f57.item). 2.As of 07 September 2021, the Pinakes database, managed by the Institut de Recherche et d'Histoire des Textes (IRHT), lists the manuscript Parisinus gr. 1611 among the direct manuscript witnesses of the homily In transfigurationem Domini (CPG 5807; BHG 1980). Pinakes|Пívaкes - Notice: Proclus Constantinopolitanus, Hom 8: In transfigurationem Domini (https://pinakes.irht.cnrs.fr/ notices/oeuvre/6924/). 
As far as the present author has been able to ascertain, this is all that is publicly known to date about the text preserved in folios 46r-55r of the manuscript Parisinus $g r$. 1611. In what follows, I intend to provide a brief introduction to the codex Parisinus gr. 1611, to place the codex among the great collections of manuscripts according to the typology adopted by Albert Ehrhard and generally preserved in hagiographic and liturgical studies and to shed some light on the uncertainty that persists to this day about the contents of folios $46 r-55 r$, which are suspected of either preserving the entire homily In transfigurationem Domini (CPG 5807; BHG 1980) or a recension of it.

\section{The codex Parisinus gr. 1611: Its provenance}

A comprehensive description of the codex Parisinus gr. 1611 did not appear until 1993. Prior to this, the codex had been very briefly described in works on large manuscript collections. For example, Henri Omont, who provided the first information on the origin and content of this codex in his description of the Greek manuscript collection held in the French national library, lists the works preserved in the manuscript and tells us that the manuscript was copied in 1553 by a priest named Demetrius, ${ }^{3}$ that it is a codex on paper, containing 445 folios, and that in the manuscript collection of Jean-Baptiste Colbert, ${ }^{4}$ it was inventoried under number 4719 (Omont 1888:106). Further details were to appear in 1950, in an article by Jean Darrouzès on Cypriot manuscripts in the French national library. Jean Darrouzès wrote:

At the same time, it should be observed that in folio 438 the same Demetrius gave the date of his ordination in 1550 and the date of his brother's death in 1557. It is not the same hand that wrote the colophon. Demetrius could be none other than a companion or the one who commissioned the manuscript. The volume became the property of John Logaras, according to folio Ar, and later became the property of the monastery of Arakos [in Cyprus], according to folio Av (Darrouzès 1950:191) (Author's own translation).

Costas N. Constantinides and Robert Browning were to describe the contents of the manuscript in detail, providing the incipit of each individual text and the number in the Bibliotheca Hagiographica Graeca (Constantinides \& Browning 1993:327-329). Also, by carefully reading the colophon in red at folio $437 \mathrm{v}$, they were able to clarify the question of the manuscript's origin. According to this colophon, 'the precise date of the completion of the volume is Wednesday, 07 June 1553' and the priest Demetrios Demetrakes is not the scribe of the volume, but the sponsor of the manuscript (Constantinides \& Browning 1993:329). Apart from folios $31 \mathrm{v}-33 \mathrm{v}$, because of an anonymous hand, the volume

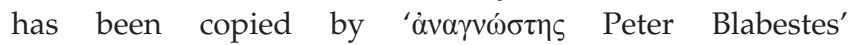
(Constantinides 2000:272; Constantinides \& Browning

\section{Erroneous information, as we will see below.}

4.Jean-Baptiste Colbert (1619-1683), former minister to King Louis XIV (1643-1715) during the years 1661-1683. With regard to the question of when the codex came into Colbert's possession, Donald Jackson has provided some information. According to him, the manuscript arrived from Cyprus in Paris on 23 November 1677 (Jackson 2010:53). Jackson relies on the arrival lists of Colbert's manuscripts, published by 2010:53). Jackson relies on the arrival lists of Colbert's manuscripts, published by
Omont in the second volume of his Missions (1902:975-977). It passed to the Royal Omont in the second volume of his Missions (1902:975-977). It passed to the Royal
Library in 1732 and thus later became part of the Bibliotheque Nationale of France.
1993:329). Constantinides and Browning (1993:331) also supply details of the manuscript illuminations, binding, quire composition and later notes.

\section{The codex Parisinus gr. 1611: Its place in the great manuscript collections}

Concerning the place of this codex among the great manuscript collections, we find information on this in the fourth volume of Ehrhard's work on the Tradition of the hagiographic and homiletic literature of the Greek Church (Ehrhard 1952). This codex is listed by Ehrhard in the category of 'mixed collections' (die gemischten Sammlungen) (1952:792874) of the large group of 'post-metaphrastic collections' (die nachmetaphrastischen Sammlungen) (1952:789-894). The 'postmetaphrastic collections', together with the 'pre-metaphrastic collections' (die vormetaphrastischen Sammlungen), are the two parts of what Ehrhard called 'non-menological collections' (die nichtmenologischen Sammlungen), which he defines as those hagiographic or homiletic manuscripts whose texts are not ordered according to the criteria of the calendar of saints or the movable church year, but follow each other randomly in an eclectic mix (1952:725-727). Ehrhard rejects the hypothesis that these collections are based on a different calendar of saints. He bases his rejection of the hypothesis on the fact that such mixed collections are found in all the larger manuscript collections next to the other collections, which are all arranged according to the single Byzantine calendar and the same single church year. Ehrhard is keen to point out, however, that one thing can be deduced from this lack of liturgical order, namely that these texts were not usually intended for the official Liturgy. Rather, they were intended for private reading, for which the exact order and sequence of feasts and Sundays of the Church year was unnecessary. ${ }^{5}$ Their design for private use can be further deduced from the fact that most of them are in small format, unlike large liturgical collections, which have a large format. Thus, Ehrhard suggests, it was very easy to place them on a private bookshelf. Furthermore, texts maintained in private collections had the advantage of evading the process of living evolution to which the officially read texts were subjected (Ehrhard 1952:725-727). Ehrhard's hypothesis that such collections were intended for private use seems to explain why only a single manuscript witness is known for the homily In transfigurationem Domini (BHG ${ }^{n}$ 1980a).

It is surprising, however, that Ehrhard does not mention folios $46 r-55 r$ in his description of the codex. He is very attentive to hagiographic texts, distinguishing between premetaphrastic and metaphrastic ones. He also comments on the Constantinopolitan origin of the nine homilies provided as readings for Sundays 10-12, 14 and 15, in which the Gospel of Luke is read, and for the Sundays 2-5, in which they are read from the Gospel of Matthew, but says nothing here about folios 46r-55r (Ehrhard 1952:865-867).

5.From these mixed collections, the dates of the feasts are usually missing and are replaced by order numbers. Also missing are the headings for each day and the order numbers (Ehrhard 1952:726). 
TABLE 1: The first part of the homily In transfigurationem Domini (BHGn 1980a) in the codex Parisinus gr. 1611, folios 46r-48v.

\begin{tabular}{|c|c|}
\hline $\begin{array}{l}\text { f. } 46 r, \\
\text { f. } 46 v\end{array}$ & 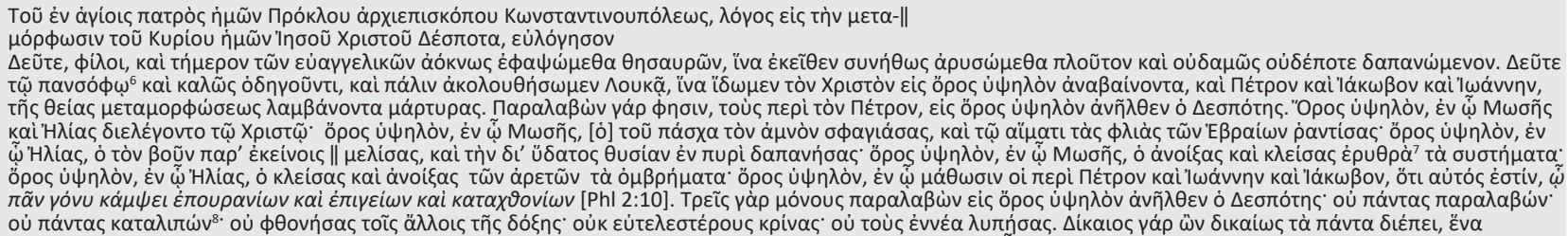 \\
\hline f. $47 v$ & 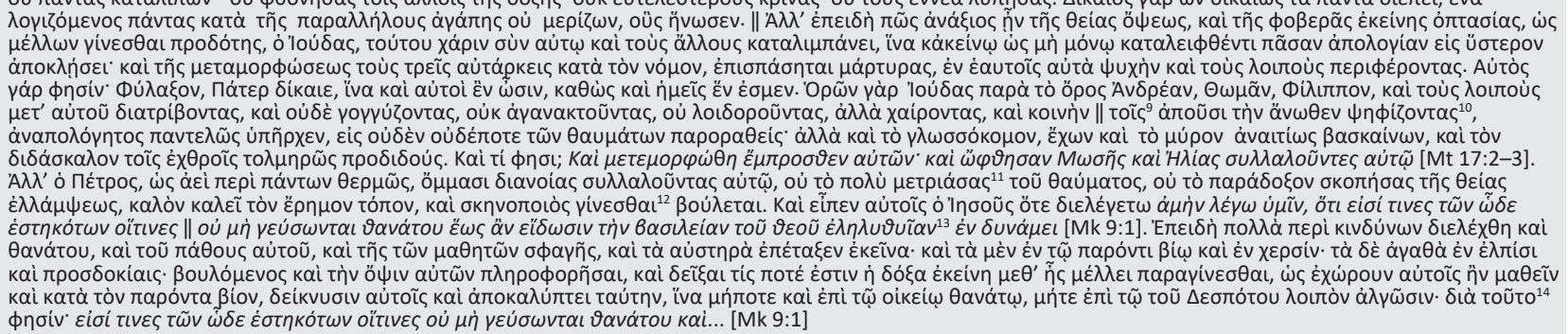 \\
\hline
\end{tabular}

\section{A first close look at the folios $46 r-55 r$ of the codex Parisinus gr. 1611}

An examination of folios $46 \mathrm{r}-55 \mathrm{v}$ brings to light an unexpected surprise. As the text preserved by these folios is unedited, I will provide here the first transcription of folios $46 \mathrm{r}-48 \mathrm{v}$ (see Table 1). It should be observed that the text in the Parisian manuscript has a large number of spelling variations. In order not to clutter up the footnotes, I will indicate here the most frequent spelling variants encountered. For example, there are numerous variations of:

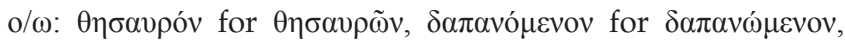

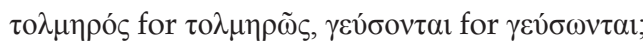

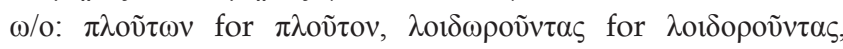

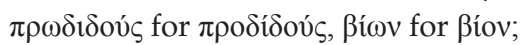

iotacism: $\eta$ for $1: \mu \varepsilon \lambda \eta \dot{\sigma \alpha \varsigma}$ instead of $\mu \varepsilon \lambda i$ $\sigma \alpha \varsigma ;$

$\imath$ for $v$ : $\alpha \rho \rho \imath \sigma \dot{\mu} \mu \varepsilon \theta \alpha$ instead of $\dot{\alpha} \rho v \sigma \omega ́ \mu \varepsilon \theta \alpha$;

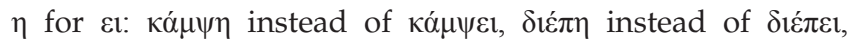

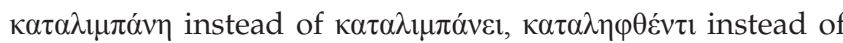
$\kappa \alpha \tau \alpha \lambda \varepsilon 1 \varphi \theta \varepsilon \dot{v} v 1, \pi \alpha \rho \circ \rho \alpha \theta \tilde{\eta} \varsigma$ instead of $\pi \alpha \rho \circ \rho \alpha \theta \varepsilon i ́ \zeta, \mu \alpha \theta \dot{\eta} v$ instead of $\mu \alpha \theta \varepsilon \tilde{\varepsilon} v$;

$\eta$ for ol: $\dot{\varepsilon} \alpha v \tau \tilde{\eta} \varsigma$ instead of $\dot{\varepsilon} \alpha v \tau$ oĩ

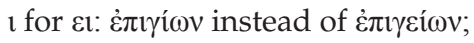

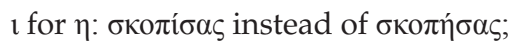

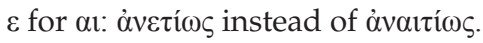

Scholars who have previously commented on this text Omont, Halkin, Geerard, Noret, Sachot, Constantinides

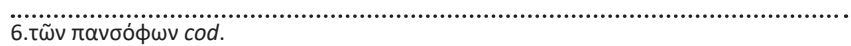

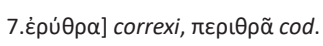

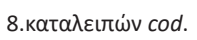

9.זก̃ cod.

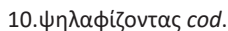

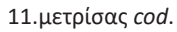

12. púvetaı cod.

13. $\dot{\lambda} \lambda \eta \lambda \cup \theta \varepsilon \tilde{\alpha} \alpha \operatorname{cod}$.

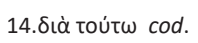

and Browning - have pointed out, we are dealing with a homily on the Transfiguration under the name of Saint

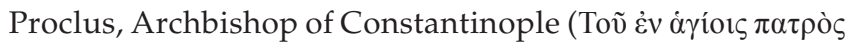

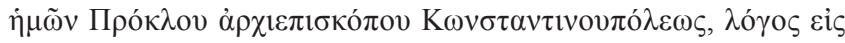

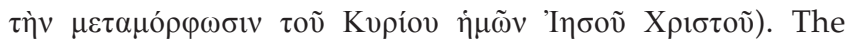
incipit of the text, as already indicated, is identical with the incipit of the homily In transfigurationem Domini (CPG 5807; BHG 1980). ${ }^{15}$ However, the following text (f. $46 \mathrm{v}-48 \mathrm{r}$ ) is not identical to the text of the homily CPG 5807 published in volume 65 of Patrologiae Graecae (1862:65:764B1-765B8). In addition to some grammatical differences, there are also a few omissions, inversions and word substitutions in the Paris manuscript text. For example, the Paris

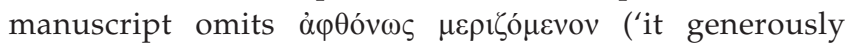
shares') (Daley 2013:89) from the first sentence of the homily (see Table 2).

Also, the Paris manuscript text omits the brief passage in which it is said that Moses and Elijah represent the Law and the prophets, who now converse with grace (öpos vi $\psi \eta \lambda$ òv, $\dot{\varepsilon} v$

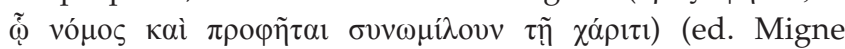
1862:65:764B.11-12). Elsewhere, the copyist of the homily chooses to rearrange the text in a logical order (see Table 3).

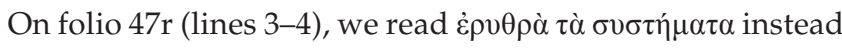

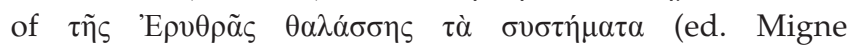
1862:65:764C.3).

TABLE 2: The beginning of the homily In transfigurationem Domini (CPG 5807; $B H G$ 1980) and the beginning of the homily on the Transfiguration in the codex Parisinus gr. 1611.

Migne 1862:65:764B.1-4 Parisinus gr. 1611, folio 46v, lines 2-6

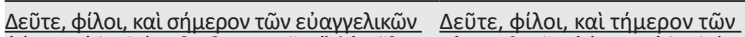

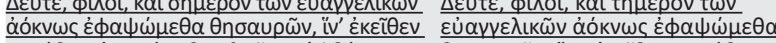

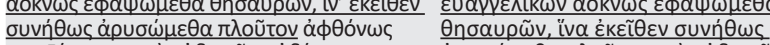

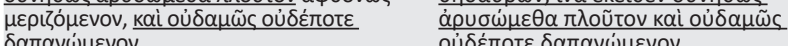

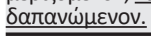

TABLE 3: A variant reading.

\section{Migne 1862:65:764C.3-5} Parisinus gr. 1611, folio 47r, lines 4-6

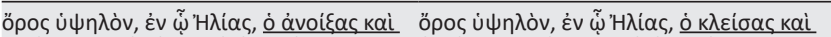

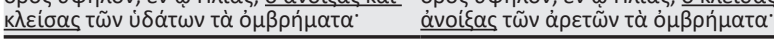

15.For his edition of homily CPG 5807, Jean-Paul Migne used Riccardi's text (ed. 1630:297-303). 
TABLE 4: Another source of homily In transfigurationem Domini (BHG 1980a).

\begin{tabular}{|c|c|c|c|}
\hline Parisinus gr. 1611 , folios $48 v-49 r^{17}$ & Migne 1862:58:549.10-22 & Cramer 1840:351.26-352.16 & $\begin{array}{l}\text { Proiou \& Schirò 1980:43 = Delehaye } \\
\text { 1902:869-870 }\end{array}$ \\
\hline 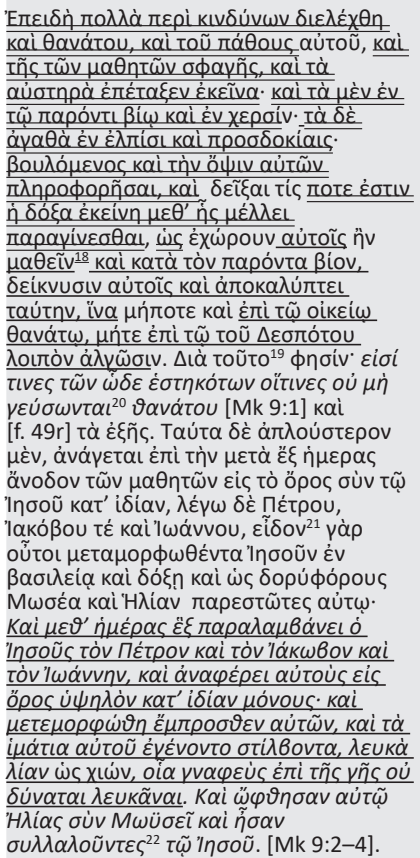 & 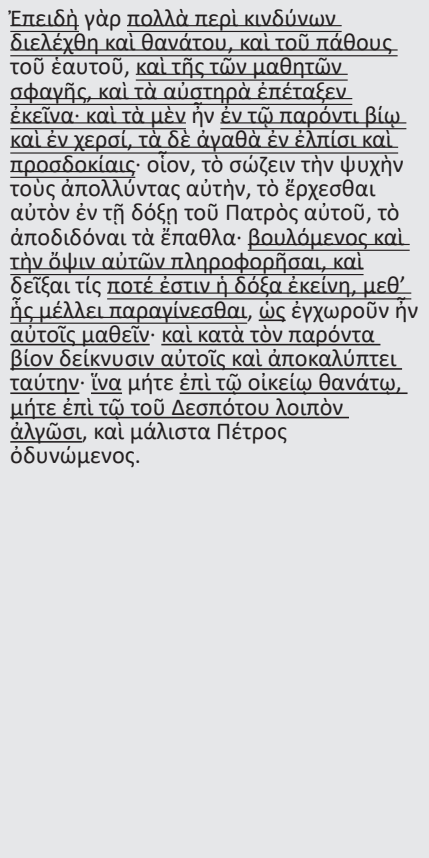 & 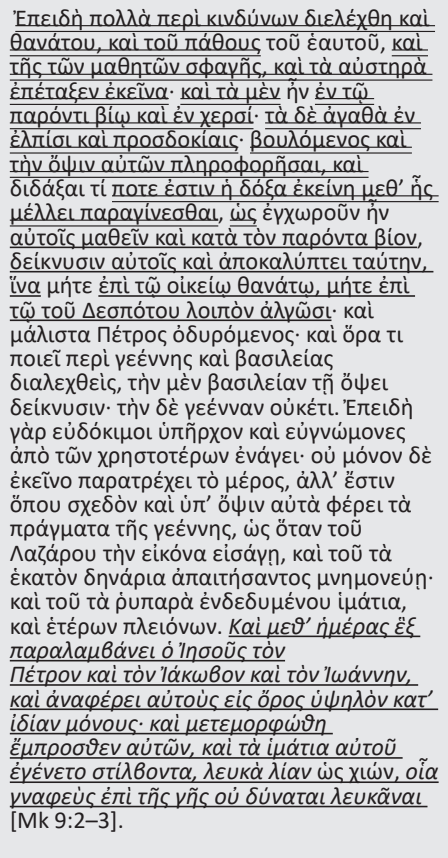 & 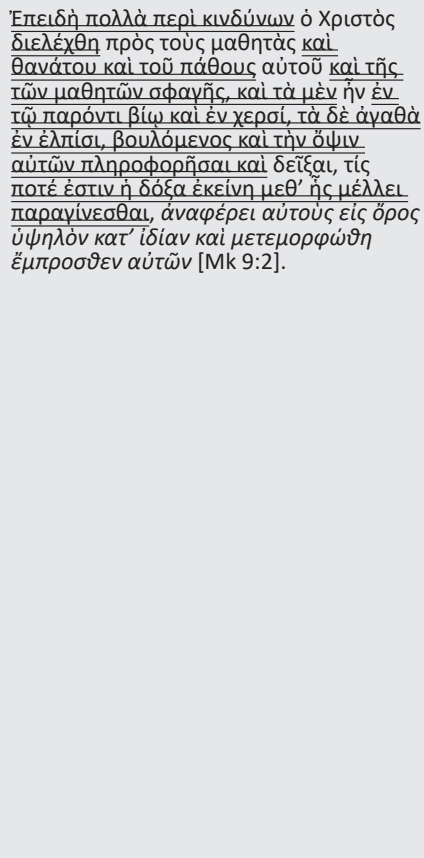 \\
\hline
\end{tabular}

The similarity with the homily CPG 5807, however, stops abruptly at the end of folio 48r, when the text from Mk 9:1 is quoted. What follows is a passage that bears a very close resemblance to the section on the Transfiguration in Catena in Marcum, edited by Cramer, ${ }^{16}$ and to the first part of the Synaxarion of Constantinople (or Synaxarion of the Great Church) and the Byzantine Synaxarion on the Feast of the Transfiguration, celebrated on 6 August. Before appearing in Catena in Marcum and as a notice for the Synaxarion of Constantinople, the beginning of the second element of our composite text is first and above all borrowed from the beginning of Chrysostom's homily 56 in Matthaeum (ed. Migne 1862:58:549.10-21), which is devoted to the exegesis of the episode of the Transfiguration. Sachot recalls in his article of 1983 that the Chrysostomic commentary on the Gospel of Matthew was a source of the recension II of the exegetical chain on Mark (Sachor 1983:124; see also Geerard 1980:236). In the following, I will present this similarity by placing in a table the text transmitted by the Parisian manuscript, the beginning of Chrysostom's homily 56 in Matthaeum, the beginning of the exegesis to the episode of the Transfiguration in Catena in Marcum, and also the beginning part of the Synaxarion to the Transfiguration (see Table 4).

\section{Concluding remarks}

As discussed, the homily In transfigurationem Domini $\left(B H G^{n}\right.$ 1980a) is not a recension of the homily In transfigurationem Domini (CPG 5807; BHG 1980), nor is it another homily on the

16.For his edition, Cramer used one 10th century codex, Parisinus gr. 178, and two 11th century codices, Oxoniensis Bodleianus Laudianus gr. 33 and Parisinus Coislinus 23. According to the Pinakes database, there are currently no less than 30 known manuscript records for Catenae in Marcum. Pinakes| Пivakec - Notice: Catenae, In Marcum (https://pinakes.irht.cnrs.fr/notices/oeuvre/8183/), last accessed on 06 October 2021. On the origins of the Catena in Marcum, see Lamb (2012:27-73).
Transfiguration by Archbishop Proclus of Constantinople. Rather, it is a compilation in the composition of which the author decided to use the beginning of the homily CPG 5807 (ed. Migne 1862:65:764B1-765B8). If he were still alive, Michel Aubineau would probably have once again exclaimed 'un inédit fantôme disparaît', as he did when he dashed the Bollandist Halkin's hopes for the existence of an unknown homily attributed to Proclus in the manuscript Metochii Sancti Sepulchri (today Atheniensis) 163, saec. XVI (Aubineau 1983:424). So we are not wrong to say that folios $46 \mathrm{r}-48 \mathrm{r}$ are the third indirect manuscript witness to the homily In transfigurationem Domini (CPG 5807; BHG 1980), and that the manuscript Parisinus gr. 1611 should be added to the list of indirect witnesses, alongside the manuscripts Vaticanus $g r$. 604 and Romanus Angelicus gr. 125 (T.1.7) (see Gârbacea 2021a, 2021b). Note that unlike the first two indirect witnesses, which transmit passages from the homily CPG 5807 under the name of John Chrysostom, the third indirect witness transmits the fragment under the name of Proclus.

Finally, it is legitimate to wonder who compiled this homily for the composition of which the homily CPG 5807 and Catena in Marcum were used. What is certain is that to date no other manuscript witness is known. This does not exclude the

17.The copy used by Peter Blabestes seems to belong to the same family of manuscripts as codex Laurentianus Pluteus gr. VI.18, saec. 10, available online at Biblioteca Medicea Laurenziana - Scaffale Digitale (bmlonline.it), last accessed on 6.10.2021. Compare, for example, ff. 48v-49r of Parisinus gr. 1611 with f. $113 \mathrm{v}$ of the Florence codex. It can be seen that the differences are very small.

18. $\mu \alpha \theta \dot{v} \operatorname{cod}$.

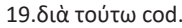

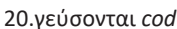

21.îoov cod.

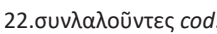


possibility that the copyist Peter Blabestes compiled this text. Although he wants to humble himself by claiming in the colophon at the end of the manuscript (f. 437v) that he does not know the divine teachings, and he puts the completion of the

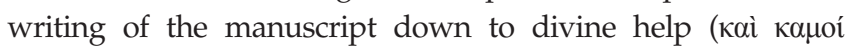

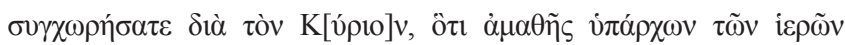
$\gamma \rho \alpha \mu \mu \alpha \dot{\tau} \omega v)$, nevertheless his self-proclaimed status as a 'reader' ( $\dot{\alpha} v \alpha \gamma v \omega ́ \sigma \tau \varsigma)$ tells us that he was very familiar with the patristic writings. Such a hypothesis waits, of course, to be proved.

\section{Acknowledgements}

The author would like to express his gratitude to Pierre Augustin for his valuable comments on the first draft of this article.

\section{Competing interests}

The author declares that he has no financial or personal relationships that may have inappropriately influenced him in writing this article.

\section{Author's contributions}

R.G. is the sole author of this research article.

\section{Ethical considerations}

This article followed all ethical standards for research without direct contact with human or animal subjects.

\section{Funding information}

Project is financed by Lucian Blaga University of Sibiu and the Hasso Plattner Foundation research grants LBUS-IRG-2019-05.

\section{Data availability}

Data sharing is not applicable to this article as no new data were created or analysed in this study.

\section{Disclaimer}

The views and opinions expressed in this article are those of the author and do not necessarily reflect the official policy or position of any affiliated agency of the author.

\section{References}

Aubineau, M., 1983, 'Un inédit fantôme. Proclus, In Transfigurationem (BHG 1974s)', Analecta Bollandiana 101(3-4), 423-424. https://doi.org/10.1484/J.ABOL.4.03098 Biblioteca Medicea Laurenziana, Homepage, viewed n.d, from http://mss.bmlonline.it/.
Constantinides, C.N., 2000, 'Scriptoria in Sixteenth-Century Cyprus', in S. Patoura

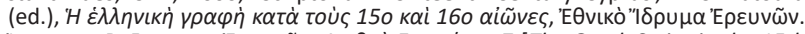

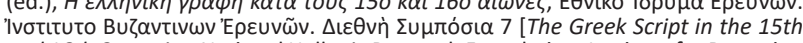

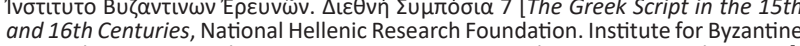
Research. International Symposium 7, pp. 261-282, Athens 18-20 October 1996],

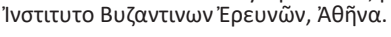

Constantinides, C.N. \& Browning, R., 1993, Dated Greek Manuscripts from Cyprus to the Year 1570, Dumbarton Oaks Studies 30, Dumbarton Oaks Research Library and Collection/Cyprus Research Centre, Washington, DC/Nicosia.

Cramer, J.A. (ed.), 1840, Catenae Graecorum patrum in Novum Testamentum, Vol. 1: In Evangelia S. Matthaei et S. Marci, Oxford University Press, Oxford.

Daley, S.J.B.E. (transl.), 2013, Light on the Mountain: Greek Patristic and Byzantine Homilies on the Transfiguration of the Lord, Popular Patristic Series 48, St Vladimir's Seminary Press, New York, NY.

Darrouzès, J., 1950, 'Les manuscrits originaires de Chypre à la Bibliothèque Nationale de Paris', Revue des études byzantines 8, 162-196. https://doi.org/10.3406/ rebyz.1950.1028

Delehaye, H. (ed.), 1902, Synaxarium ecclesiae Constantinopolitanae (e codice Sirmondiano nunc Berolinensi), Society of Bollandists, Brussels.

Ehrhard, A., 1952, Überlieferung und Bestand der hagiographischen und homiletischen Literatur der griechischen Kirche von den Anfängen bis zum Ende des 16. Jahrhunderts, Band III/2 Texte und Untersuchungen zur Geschichte der altchristlichen Literatur 52/2, Akademie Verlag Berlin in Arbeitsgemeinschaft mit dem J.C. Hinrichs Verlag, Leipzig.

Gârbacea, R., 2021a, 'A few remarks on the Inedita Pseudo-Chrysostomic Homily De transfiguratione et eleemosyna (CPG 5009; BHGn 1996t)', HTS Teologiese Studies/ Theological Studies 77(4), a6686. https://doi.org/10.4102/hts.v77i4.6686

Gârbacea, R., 2021b, 'A new indirect witness to In Transfigurationem Domini (CPG 5807): Codex Romanus Angelicus gr. 125 (T.1.7)', in M. Vinzent (ed.), Studia Patristica CXXVIII: Papers presented at the Eighteenth International Conference on Patristic Studies held in Oxford 2019, pp. 363-371, Peeters, Leuven.

Geerard, M., 1979, Clavis Patrum Graecorum III: ab Cyrillo Alexandrino ad Iohannem Damascenum, Brepols, Turnhout.

Geerard, M., 1980, Clavis Patrum Graecorum IV: Concilia, Catenae, Brepols, Turnhout.

Geerard, M. \& Noret, J., 2003, Clavis Patrum Graecorum III: ab Cyrillo Alexandrino ad Iohannem Damascenum, Editio secunda, anastatica, addendis locupletata, Brepols, Turnhout.

Grec 1611|Gallica, Homepage, viewed n.d, from https://gallica.bnf.fr/ark:/12148/ btv1b107234374/f57.item.

Halkin, F., 1968, Manuscripts grecs de Paris. Inventaire hagiographique, Subsidia Hagiographica 44, Société des Bollandistes, Bruxelles.

Halkin, F. (ed.), 1969, Auctarium Bibliothecae Hagiographicae Graecae, Subsidia Hagiographica 47, Société des Bollandistes, Bruxelles.

Halkin, F. (ed.), 1984, Novum Auctarium Bibliothecae Hagiographicae Graecae, Subsidia Hagiographica 65, Société des Bollandistes, Bruxelles.

Jackson, D., 2010, 'The Colbert Greek Library from 1676 to 1678', Codices Manuscript 73-74, 43-57.

Lamb, W.R.S., 2012, The Catena in Marcum. A Byzantine Anthology of Early Commentary on Mark, Text and Editions for New Testament Study 6, Brill, Leiden.

Leroy, F.J., 1967, L'homilétique de Proclus de Constantinople: Tradition manuscrite, inédits, études connexes, Studi e testi, 247, Biblioteca Apostolica Vaticana, Città del Vaticano.

Migne, J.-P. (ed.), 1862, Patrologiae cursus completus: Series graeca, 162 vols., Migne, Paris.

Omont, H., 1888, Inventaire sommaire des manuscrits grecs de la Bibliothèque nationale et des autres bibliothèques de Paris et des Départements, vol. 3, Alphonse Picard, Paris.

Omont, H., 1902, Missions archéologiques françaises en Orient aux XVIle et XVIIle siècles, Collection de Documents inédits sur I'histoire de France, vol. 2, Imprimerie Nationale, Paris.

Pinakes|Пívaкєৎ - Notice: Proclus Constantinopolitanus, Hom 8: In transfigurationem Domini, viewed nd., from https://pinakes.irht.cnrs.fr/notices/oeuvre/6924/.

Pinakes|Пívaкєऽ - Notice: Catenae, In Marcum, viewed n.d., from https://pinakes. irht.cnrs.fr/notices/oeuvre/8183/.

Proiou, A. \& Schirò, J. (eds.), 1980, Analecta Hymnica Graeca. XII: Canones Augusti, Istituto di studi bizantini e neoellenici, Università di Roma, Roma.

Sachot, M., 1983, 'Le réemploi de l'homélie 56 in Matthaeum de Jean Chrysostome (BHGa 1984) dans deux homélies byzantines sur la Transfiguration (BHG 1980k et ' 1985 )', Revue des sciences religieuses 57(2), 123-146. https://doi.org/10.3406/rscir.1983.2973

Sachot, M., 1987, Les homélies grecques sur la transfiguration: Tradition manuscrite, Éditions du centre national de la recherche scientifique, Paris. 